\title{
Arab-Muslims Contributions to Modern Neuroscience: What's Giving Us Hope?
}

\author{
Wael Mohamed, MD, PhD, MSc
}

${ }^{1}$ Clinical pharmacology department, Menoufia Medical School, Menoufia University, Egypt

${ }^{2}$ Basic Medical Science Department, Kulliyyah of Medicine, International Islamic University Malaysia (IIUM), Pahang, Malaysia

wmy107@gmail.com

\begin{abstract}
The Arab world encompasses a broader geographical area, covering a wide variety of countries in Asia and Africa. Arab culture is due to much of its development in all the fields of intellectual practice, including in medicine, particularly during the Golden Age of the Arabic Islamic sciences (8th - 13th centuries C.E.). The glorious history of the Arab world allows us to consider the debt of mankind to the golden age of Arab science and assess the contribution of Arab countries to our day's biomedical and neuroscience research.
\end{abstract}

\section{Introduction}

Medicine did not develop overnight. The civilizations of Egypt, Greece, Rome, Persia, India, China and the European Renaissance took up the responsibility of the flame of medic al development. During the Dark Ages the medical flame was taken up by the Arabic-Islamic world. The period between the 7th and 13th centuries has been commonly neglected, despite the remarkable developments of biomedical science of the Arabic-Islamic world with the resultant flowering of knowledge that influenced medic al practice throughout Europe (Falagas et al., 2006; Matthew et al., 2018). We could say that the history of any nation is equal to the sum of the history of a few of its distinguished individuals. At every stage in Arabic medical history, we can find outstanding people whose greatest contributions and efforts cannot be underestimated.

Some scholars have referred to the achievements in the growth of the knowledge of medieval Arab culture as pure translation and preservation of Greek knowledge. The original works in Arabic are believed to have only been retained and duplicated. They had no curiosity for learning, and so their insights, intuitions, and cognition were immature. But nonetheless investigations are meant to be the triumph of recent years. Arabs stressed their essential instruments of growth in science and critical thought and medicine creation as stated in the Al-Razi declaration "any physician who is dependent only on his experimentation and neglect literary knowledge and hypothesis then he may be a failure". 
The Arabs have accomplishments in original medical innovations which made them the sole source of many learning scholars. They had excelled in many innovations like bed side clinics, differential diagnosis between smallpox and measles, concepts of mobile clinics, pharmacy, emergency facilities, midwifery, separate pediatrics facilities and advancement in the fields of psychiatry, cardiology, ophthalmology etc. (Ahmed et al., 2017).

The scientific contributions of Arab-Muslims cannot be overlooked, and their contributions call for their names to be written with the golden painting of history. Today, technical advances and innovations have shocked and blurred the world and these changes have not been suddenly made! Isn't it just the last 200 years of effort? The foundations of science were not only laid by European thinkers. Prof. Hitti and some other scholars said it is evident that we had outstanding illustrations that the Arabs put up innovative gifts for medieval Europe the investigations of Greek and Roman scholars; medicine, astronomy, mathematics and philosophy (Beg, 2015; Hitti, 1938; Rashid, 2010). The objective of this report is to analyze the expansion of knowledge in the field of neuroscience in Arabs. The current article shall illustrate this with some examples of those whose books contributed towards the development of Medieval European neuroscience.

\section{Terminology}

The modern discipline of psychology began in the 19th century. In the pre-modern context, the term 'psychology' refers to the study of human mind and behavior, while the term 'mind' refers to human intellect and consciousness. So, it must be made clear that medieval Islamic psychology does not deal with the mind only (Ashy, 1999). Early Arab and Muslim scholars wrote extensively about human psychology. They used the term Nafs (self or soul) to indicate individual personality and the term fitrah (nature) as an indication for human nature. Nafs is a broad term that includes the qalb (heart), the ruh (spirit), the aql (intellect) and irada (will). Early Muslim scholars had a certain philosophy in their writing that encompassed all areas of human enquiry, i.e. the knowledge of all things, both divine and human (Ashy, 1999). Therefore, Islamic psychology, or Ilm-al Nafsiat (psychological sciences), refers to the study of Nafs (self or psyche) and is related to psychology, psychiatry and neurosciences (Deuraseh and Abu Talib, 2005). Al-ilaj al-nafsy (psychological therapy) in Islamic medicine is simply defined as the study of mental illness and is equal to psychotherapy, as it deals with curing/treatment of ideas, soul and vegetative mind. The psychiatric physician was referred to as al-tabib al-ruhani or tabib al-qalb (spiritual physician) (Deuraseh and Abu Talib, 2005). Moreover, the Islamic and Arabic psychological era includes the establishment of the first mental hospitals, the development of the first clinical approach to mental illness, and a unique experimental approach to the study of the mind 
(Khaleefa, 1999; Paladin, 1998).

\section{Neuroscience and psychology}

Islamic medicine stressed the need for the understanding of human mental health. The first psychiatric hospitals and insane asylums were built in the Islamic world in Baghdad in 705, Fes (the third largest city in Morocco) in the 8th century, Cairo in 800, Damascus and Aleppo in 1270 (Syed, 2002). The most characteristic features of medieval Muslim psychotherapy were the use of clinical observations of mentally ill patients, which resulted in the provision of ground-breaking applications of moral treatment, baths, drug medic ation, music therapy and occupational therapy (Syed, 2002). The concepts of mental health and mental hygiene were introduced by the Muslim physician Ahmed ibn Sahl al-Balkhi (850-934) (Table 1). His book, Sustenance for Body and Soul (in arabic: Masalih al-Abdan wa al-anfus), was the first book that discussed psychosomatic diseases with an emphasis on mind and body: "if the nafs (psyche) gets sick, the body may also find no joy in life with development of a physical illness" (Deuraseh and Abu Talib, 2005). Ahmed ibn Sahl al-Balkhi was a pioneer of psychotherapy, psychophysiology, and psychosomatic medic ine. He was the first one who recognized that the body (fever, headache) and the soul (anger, anxiety and sadness) can be healthy or sick or balanced or imbalanc ed. He recognized two types of depression: one caused by known causes (physiological reasons) that can be treated through physical medic ine; and the other caused by unknown reasons that can be treated psychologically (Deuraseh and Abu Talib, 2005). Najab ud-din Muhamed (10th century) made careful observations of mentally ill patients with detailed descriptions of several mental diseases including agitated depression, neurosis, periapism and sexual impotenc e (Nafkhae Malikholia), psychosis (Kutrib) and mania (Dual-Kulb) (Syed, 2002; Youssef and Youssef, 1996). 


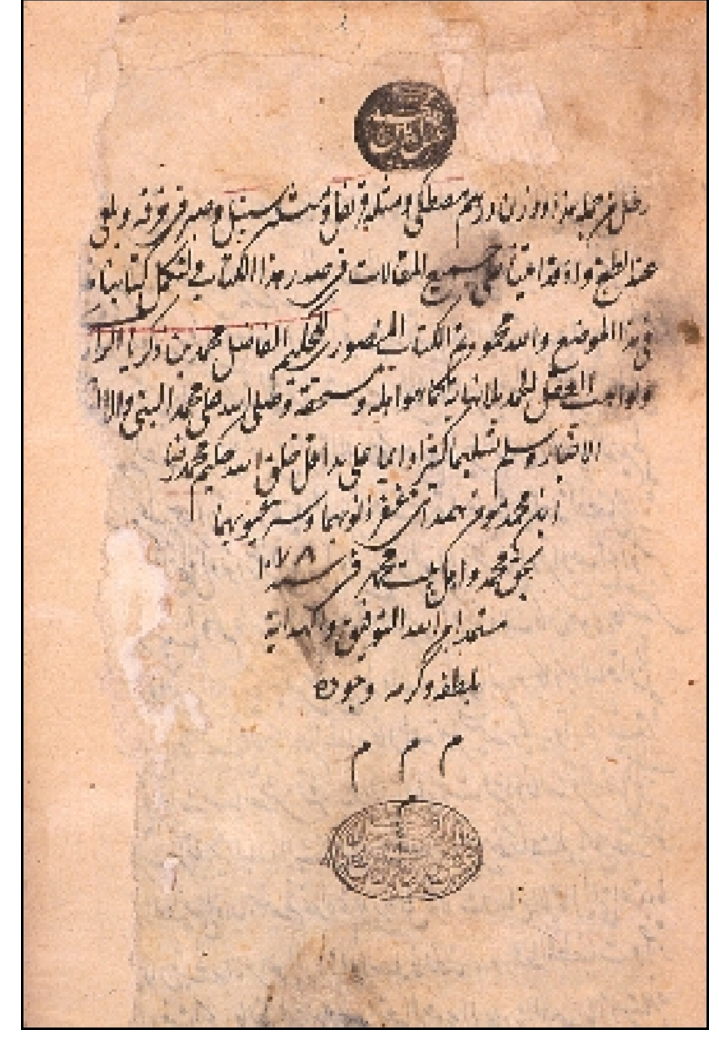

Figure 1: Razi's Book of Medicine for Mansur.

Al-Balkhi and Muhamed ibn Zakariya Razi (Rhazes) were the first known physicians to describe psychotherapy. Razi's books (El-Mansuri and Al-Hawi) formed landmarks for the description of mental illness in the 10th century and provided definitions, symptoms and treatments for problems related to mental health and mental illness. Razi was also the director of a unique psychiatric ward in a Baghdad hospital. Such psychiatric clinics did not exist in Europe during that time for fear of demonic possessions (Figure 1) (Syed, 2002 Ibn al-Haytham (Figure 2) is the founder of the experimental psychology and psychophysics (Khaleefa, 1999) with his distinguished book on the psychology of visual perception, Book of Optics (Steffens, 2006). Ibn al-Haytham was the first scientist to argue that vision occurs in the brain rather than the eyes in his Book of Optics (Edition III). Moreover, he pointed out that personal experience influences what people see and how they see, and that vision and perception are subjective feelings (Steffens, 2006).

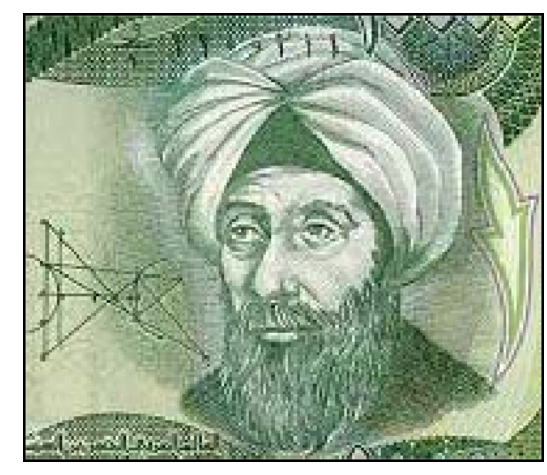

Figure 2: Ibn al-Haytham. 
Al-Biruni (Figure 3) was a pioneer in experimental psychology as he was the first person to describe empiric ally the concept of reaction time (Iqbal, 1999): "Not only is every sensation attended by a corresponding change localized in the sense-organ, which demands a certain time, but also, between the stimulation of the organ and consciousness of the perception an interval of time must elapse, corresponding to the transmission of stimulus for some distance along the nerves."

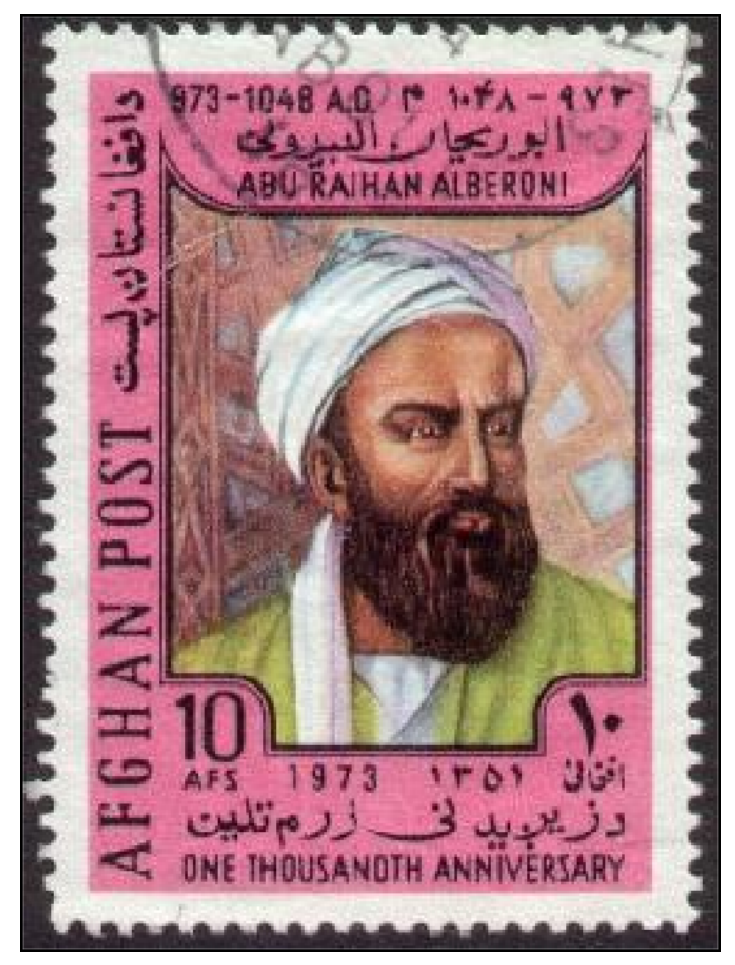

Figure 3: Abu Baihan Alberuni. Afghanistan postage stamp, 1973.

Ali ibn Abbas al-Majusi (AD 982) discussed how the physiological and psychological aspects of a patient can influence one another in his famous book, Complete Book of the Medical Art. He found a correlation between patients who were physically and mentally healthy and those who were physically and mentally unhealthy and concluded that "joy and contentment can bring a better living status to many who would otherwise be sick and miserable due to unnecessary sadness, fear, worry and anxiety" (Deuraseh and Abu Talib, 2005). He is also the first person to discuss in detail such mental disorders as sleeping sickness, memory loss, coma, meningitis, vertigo, epilepsy, and hemiplegia. Moreover, he emphasized the preservation of health through diet and natural healing as much as on medication or drugs (Haque, 2004). 
Table 1: Principle Islamic Physicians (quoted from Ezzat Abouleish)

\begin{tabular}{|c|c|c|c|c|c|}
\hline Name (Arabic) & $\begin{array}{l}\text { Name } \\
\text { (Latin) }\end{array}$ & $\begin{array}{l}\text { Life } \\
\text { span } \\
\text { (AD) }\end{array}$ & $\begin{array}{l}\text { Specialty } \\
\text { \& Contribution }\end{array}$ & Special books & City/Country \\
\hline $\begin{array}{l}\text { Jurjis ibn } \\
\text { Bakhtishu Jibril } \\
\text { Yuhanna ibn } \\
\text { Masawayh }\end{array}$ & & $\begin{array}{l}700- \\
800\end{array}$ & $\begin{array}{l}\text { Translation from } \\
\text { Greek } \\
\text { and Syriac into } \\
\text { Arabic }\end{array}$ & $\begin{array}{l}\text { Translation of works } \\
\text { of Hippocrates, Galen } \\
\text { and Aristotle }\end{array}$ & Baghdad \\
\hline Hunain Ibn Ishak & & $\begin{array}{l}826- \\
882\end{array}$ & & & \\
\hline $\begin{array}{l}\text { Abu Zaid Ahmed } \\
\text { ibn Sahl al- } \\
\text { Balkhi }\end{array}$ & & $\begin{array}{l}850- \\
934\end{array}$ & $\begin{array}{l}\text { Muslim psychology, } \\
\text { medicine, neuroscience }\end{array}$ & $\begin{array}{l}\text { Masalih al-Abdan wa al- } \\
\text { anfus }\end{array}$ & $\begin{array}{l}\text { Shamistiyan, } \\
\text { Persian } \\
\text { province of } \\
\text { Balkh } \\
\text { (Afghanistan) }\end{array}$ \\
\hline Al-Razi & Razes & $\begin{array}{l}841- \\
926\end{array}$ & $\begin{array}{l}\text { Internal medicine, } \\
\text { epidemiology, } \\
\text { ophthalmology, } \\
\text { chemistry, } \\
\text { physics, philosophy }\end{array}$ & $\begin{array}{l}\text { Kitab Al-Mansuri } \\
\text { (The Liber Al-Mansuris), } \\
\text { Al-Murshid, Al-Hawi } \\
\text { (Continents), } \\
\text { Al-Gudari wa, Al-Gudari } \\
\text { (de Peste or de Pestilentia) }\end{array}$ & $\begin{array}{l}\text { Kharasan, } \\
\text { Baghdad }\end{array}$ \\
\hline $\begin{array}{l}\text { Abū Nasr } \\
\text { Muhammad ibn } \\
\text { al-Farakh al- } \\
\text { Fārābi }\end{array}$ & $\begin{array}{l}\text { Alpharabi } \\
\text { us }\end{array}$ & $\begin{array}{l}872- \\
950\end{array}$ & $\begin{array}{l}\text { Political philosophy, } \\
\text { Epistemology, } \\
\text { medicine }\end{array}$ & $\begin{array}{l}\text { Purposes of metaphysic } \\
\text { Translations of works of } \\
\text { Aristotle, Focus Al- } \\
\text { Hekam, Kitab Mabda' } \\
\text { ara'ahl Al-Madina Al- } \\
\text { Fadhila }\end{array}$ & $\begin{array}{l}\text { Central Asia, } \\
\text { Iran, Iraq, Syria } \\
\text { and Egypt }\end{array}$ \\
\hline $\begin{array}{l}\text { Al-Zahrawi } \\
\text { (Abu-Al- Qasim } \\
\text { Khalaf Ibn'Abbas } \\
\text { Al- Zahrawi) }\end{array}$ & $\begin{array}{l}\text { Abulcasis } \\
\text { (Bucasis } \\
\text { Alzahraviu } \\
\text { s) }\end{array}$ & $\begin{array}{l}930- \\
1013\end{array}$ & Neurosurgery & $\begin{array}{l}\text { al-Tasrif Liman Ajiz 'an al' } \\
\text { Ta'lif }\end{array}$ & $\begin{array}{l}\text { Al-Andalus } \\
\text { (Cordova) }\end{array}$ \\
\hline $\begin{array}{l}\text { Abū Rayhān } \\
\text { Muhammad ibn } \\
\text { Ahmad Bīrun̄̄ }\end{array}$ & $\begin{array}{l}\text { Abu- } \\
\text { Rayhan } \\
\text { Biruni }\end{array}$ & $\begin{array}{l}937- \\
1048\end{array}$ & $\begin{array}{l}\text { Anthropology, } \\
\text { pharmacology, } \\
\text { psychology } \\
\text { father of } \\
\text { anthropology, } \\
\text { geodesy and } \\
\text { experimental } \\
\text { mec hanics, pioneer } \\
\text { of experimental } \\
\text { psychology }\end{array}$ & $\begin{array}{l}\text { Ta'rikh al-Hind, The } \\
\text { Mas'udi Canon, } \\
\text { Understanding } \\
\text { Astrology }\end{array}$ & Persia \\
\hline Ibn-Sina & Avicenna & $\begin{array}{l}980- \\
1037\end{array}$ & $\begin{array}{l}\text { Medical } \\
\text { encyclopedia, } \\
\text { philosophy, } \\
\text { astronomy, poetry }\end{array}$ & $\begin{array}{l}100 \text { books Al-Qanun } \\
\text { (Canon Law) (over } 1 \\
\text { million words) }\end{array}$ & $\begin{array}{l}\text { Hamazan, } \\
\text { Jurjan }\end{array}$ \\
\hline
\end{tabular}




\begin{tabular}{|l|l|l|l||l|l|}
\hline Ibn-Rushd & Averroes & $\begin{array}{l}1126- \\
1198\end{array}$ & $\begin{array}{l}\text { Philosophy, } \\
\text { medic ine, law }\end{array}$ & Kitab Al-Kulliat & $\begin{array}{l}\text { Al-Andalus, } \\
\text { Granada }\end{array}$ \\
\hline Ibn-Maimon & $\begin{array}{l}\text { Maimonid } \\
\text { es }\end{array}$ & $\begin{array}{l}1135- \\
1208\end{array}$ & $\begin{array}{l}\text { Philosophy, } \\
\text { translations Hebrew \& } \\
\text { Latin, poisons, } \\
\text { hygiene and public } \\
\text { health }\end{array}$ & $\begin{array}{l}\text { Al-Tadbir El-Sihhi, } \\
\text { Moushid El-Hairan }\end{array}$ & $\begin{array}{l}\text { Cairo } \\
\text { (Saladdin's } \\
\text { physician) }\end{array}$ \\
\hline Ibn-Al-Nafis & $1208-$ & $\begin{array}{l}\text { Pulmonary } \\
\text { circulation, blood } \\
\text { supply to the heart }\end{array}$ & $\begin{array}{l}\text { Sharah Tashrih al Qanun, } \\
\text { Al-Mujaz }\end{array}$ & $\begin{array}{l}\text { Damascus, } \\
\text { Cairo }\end{array}$ \\
\hline
\end{tabular}

Avicenna (Ibn-Sina; 980-1037) (Figure 4; Table 1) is considered as a father of modern medicine (Haque, 2004).

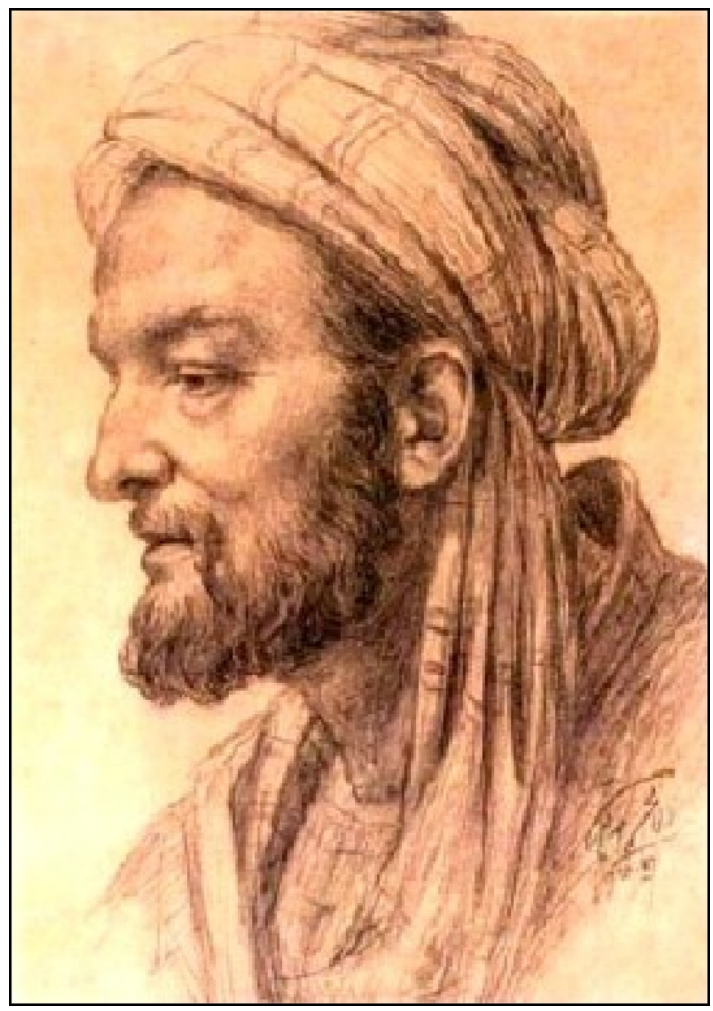

Figure 4: Avicenna - Persian physician Ibn-Sina.

It was he who first recognized 'physiological psychology' for the treatment of illness involving emotions. He was a pioneer in psychophysiology and psychosomatic medicine, developing a system for associating changes in the pulse rate with feelings. This idea was in anticipation of the word-association test attributed to Carl Jung (Syed, 2002). Moreover, Avicenna was also a pioneer of neuropsychiatry as he first described numerous neuropsychiatric conditions, including insomnia, mania, hallucinations, nightmare, dementia, epilepsy, stroke, paralysis, vertigo, melancholia and tremors (Abbasi et al., 2007). George Sarton, father of the history of science, wrote in his famous book, The Introduction to the History of Science:

"One of the most famous exponents of Muslim universalism and an eminent figure in Islamic Learning was 
Ibn Sina, known in the West as Avicenna (981-1037). For a thousand years he has retained his original renown as one of the greatest thinkers and medic al scholars in history. His most important medic al works is the Qanun (Canon) and a treatise on Cardiac drugs. The 'Qanun fi-1-Tibb' is an immense encyclopedia of medic ine. It contains some of the most illuminating thoughts pertaining to distinction of mediastinitis from pleurisy; contagious nature of phthisis, distribution of diseases by water and siol; careful description of skin troubles; of sexual diseases and perversions, of nervous ailments" (quoted from Zahoor and Haq, 1997).

The Canon of Medicine (Qanun: Law of Medicine) (Figure 5) by Ibn-Sina is one of the most famous books in the history of medicine. This book is a 14-volume medic al encyclopedia that was completed in 1025 (Stanley, 1994). This book was used in many medical schools, for example the University of Montpellier, France (1650). The book explains the causes of health and disease. Ibn-Sina believed that the human body can be healthy if the causes of health and disease are determined. He defined medicine (tibb) as the science by which we learn the different aspects of the human body in both health and disease.

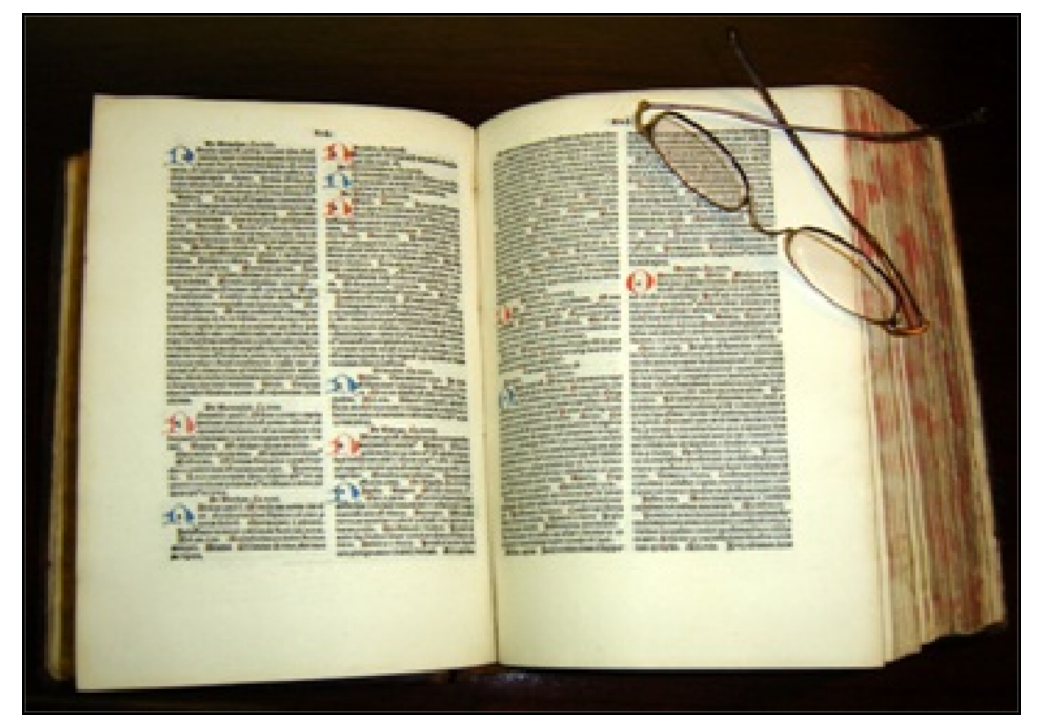

Figure 5: Latin copy of the Canon of Medicine dated 1484, PI Nixon Medical Historical Library, University of Texas Health Science Center.

The Arabic text of the Qanun was translated into Latin as the Canon of Medicine by Gerard of Cremona in the 12th century and into Hebrew in 1279. Avicenna dedicated three chapters of his book to neuropsychiatric disorders. He defined madness (Junun) as a mental disorder of reason in which reality is replaced by fantasy and he located its origin in the middle part of the brain (Youssef and Youssef, 1996). In the Canon of Medicine, Avicenna was the father of the science of psychoanalysis through his extension of the theory of temperaments to include mentality, emotions, morality, self-awareness, movements, and dreams. His four primary temperaments are summarized in Table 2 (Lutz, 2002). Later in the 13th century, Maimonides described rabies and belladonna intoxication (Araguz et al., 2002). 
Table 2: Avicenna's Four Primary Temperaments

\begin{tabular}{|l|l|l|l|l|}
\hline Evidence & Hot & Cold & Moist & Dry \\
\hline Morbid states & Inflammations become \\
febrile & $\begin{array}{l}\text { Fevers related to } \\
\text { serious } \\
\text { humour, rheumatism }\end{array}$ & Lassitude & Loss of vigour \\
\hline $\begin{array}{l}\text { Functional } \\
\text { power }\end{array}$ & Deficient energy & $\begin{array}{l}\text { Deficient digestive } \\
\text { power }\end{array}$ & Difficult digestion & \\
\hline $\begin{array}{l}\text { Subjective } \\
\text { sensations }\end{array}$ & $\begin{array}{l}\text { Bitter taste, excessive } \\
\text { thirst, burning at cardia }\end{array}$ & $\begin{array}{l}\text { Lack of desire for } \\
\text { fluids }\end{array}$ & $\begin{array}{l}\text { Mucoid salivation, } \\
\text { sleepiness }\end{array}$ & $\begin{array}{l}\text { Insomnia, } \\
\text { wakefulness }\end{array}$ \\
\hline $\begin{array}{l}\text { Physical } \\
\text { signs }\end{array}$ & $\begin{array}{l}\text { High pulse rate, } \\
\text { lassitude }\end{array}$ & Flaccid joints & $\begin{array}{l}\text { Diarrhea, swollen eyelids, } \\
\text { rough skin, acquired habit }\end{array}$ & $\begin{array}{l}\text { Rough skin, acquired } \\
\text { habit }\end{array}$ \\
\hline $\begin{array}{l}\text { Foods \& } \\
\text { medicines }\end{array}$ & $\begin{array}{l}\text { Calefacients harmful, } \\
\text { infrigidants beneficial }\end{array}$ & $\begin{array}{l}\text { Infrigidants harmful, } \\
\text { calefacients beneficial }\end{array}$ & Moist articles harmful & $\begin{array}{l}\text { Dry regimen } \\
\text { harmful, } \\
\text { humectants } \\
\text { beneficial }\end{array}$ \\
\hline $\begin{array}{l}\text { Relation to } \\
\text { weather }\end{array}$ & Worse in summer & Worse in winter & Bad in autumn \\
\hline
\end{tabular}

Avicenna was the first person to diagnose love sickness (Ishq) when he was treating a very ill patient by "feeling the patient's pulse and reciting aloud to him the name of provinces, districts, towns, streets and people". He noticed the changes in patient's pulse and decided that the patient was in love with a girl whose home Avicenna was able to locate by the digital examination of patient's pulse (Syed, 2002). Avicenna also linked physical and psychological illnesses as he described melancholia (depression) as a type of mood disorder with characteristic associated phobias. Also, he pointed to anger as a factor in the progression of melancholia to mania. He hypothesized that happiness increases the breath, leading to uncontrolled increase in brain moisture and resulting in mental disorders (Haque, 2004). Avicenna also discovered a condition resembling schizophrenia and described it as Junun Mufrit (severe madness) with characteristic symptoms such as agitation, behavioral and sleep disturbance, giving inappropriate answers to questions and occasional inability to speak. He wrote that these patients must be restrained to avoid any harm they might cause to themselves or to others (Youssef and Youssef, 2002). Avicenna discovered the cerebellar vermis which he named vermis and the caudate nucleus, which he named tailed nucleus or nucleus caudatus. These terms are still used in modern neuroanatomy and neurophysiology (Aydin, 2001). Moreover, he was the first person to relate intellectual dysfunctions to deficits in the brain's middle ventricle and frontal lobe, which mediates common sense and reasoning (Theodore, 2004). Avicenna also diagnosed facial nerve paralysis, distinguishing between paralysis and hyperemia. He also diagnosed meningitis as a disease induced by the brain itself, differentiating it from infectious brain disease. Moreover, he was able to diagnose and describe other types of 
meningitis induced by an infection in other parts of the body (Aydin, 2001).

The earliest works on social psychology and animal psychology were written by al-Jahiz (766- 868), an Afro-Arab scholar who studied the social organization of ants and animal communication and psychology (Haque, 2004). Another great scholar who was a pioneer of social psychology is Al-Farabi (Alpharabius) (Table 1; Figure 6).

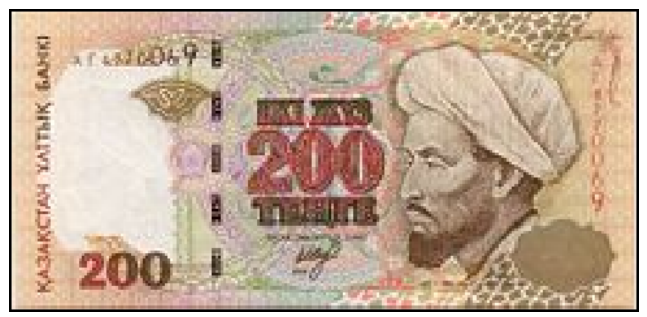

Figure 6: Al-Farabi on Republic of Kazakstan currency.

Al-Farabi was the first to state that "an isolated individual could not achieve all the perfections by himself, without the aid of other individuals ... [it is the] innate disposition of every man to join another human being or other men in the labor he ought to perform." He concluded that to "achieve what he can of that perfection, every man needs to stay in the neighborhood of others and associate with them". Furthermore, Al-Farabi could discuss the therapeutic effects of music on the soul in his treatise "Meanings of the Intellect", where he discussed the therapeutic potential of music (Hague, 2004). AlFarabi's Social Psychology and Model City were the first treaties dealing with social psychology. His book, Opinions of the People of the Ideal City, was the first book to distinguish between dream interpretation and the nature and causes of dreams (Akbar, 1984). Ibn Zuhr (Avenzoar) was the first to provide accurate descriptions of neurological disorders including intracranial thrombophlebitis and mediastinal germ cell tumors. Averroes suggested the existence of Parkinson's disease and referred to the photoreceptor properties of the retina. Maimonides wrote about neuropsychiatric disorders and described rabies and belladonna intoxication (Araguz et al., 2002).

\section{Islamic counseling and psychotherapy}

Islamic counselling and psychotherapy are the incorporation of clinical systems, methods and strategies of Islamic values, teachings, and spirituality. Islam is an integral religion that sees the individual in all respects, including mental, physical, and spiritual respects. For Islamic therapy, the well-being of these three elements is important. Therefore, it is important to include in psychotherapy methods the Quran, the hadeeth, and other aspects of Islamic culture. Nobody has ever said that there is some Islamic advice and there is no uniformly referred body regulating Islamic advice, so the question of Islamic advice is still 
widely accessible. This paper analyses selected Islamic advice and psychotherapy principles, as it also reflects the medieval tradition of Islamic counselling. In the medieval era early, Muslim authors wrote extensively about psychology of human beings or "ilm nafs. The concepts were used for the personality of the Nafs (self or soul) which included the qalb (heart), the ruh (spirit), the ,aql (intellect) and the irada (will) and the fitrah (human nature) (see Sudan, 2017).

When Al-Razi was appointed as a physician-in-chief at Baghdad Hospital, he made it the first hospital in history to have a ward devoted to mentally ill patients. Razi was considered the first person to combine psychological methods and psychological explanations and to use psychotherapy in an applicable fashion. Razi was once called to treat a famous caliph who had severe arthritis. Razi advised a hot bath and, while the caliph was bathing, Razi threatened him with a knife, proclaiming he was going to kill him. This deliberate provocation increased the natural caloric, thus creating sufficient strength to dissolve the already softened humours. As a result, the caliph got up from his knees in the bath and ran after Razi. Najab ud din Muhammad, a contemporary of Razi, left many excellent descriptions of mental diseases. His carefully compiled observations of patients comprised the most complete classification of mental diseases known before then. Najab described agitated depression, obsessional types of neurosis, Nafkhae Malikholia (combined priapism, sexual impotenc e), Kutrib (a form of persecutory psychosis) and DualKulb (a form of mania).

Avicenna often used psychological methods to treat his patients. One of his patients was a prince of Persia who had melancholia and suffered from the delusion that he was a cow, and who would low like a cow crying "Kill me so that a good stew may be made of my flesh" and would never eat anything. Avicenna was persuaded to take on the case and sent a message to the patient, asking him to be happy as the butcher was coming to slaughter him, and the sick man rejoiced. When Avicenna approached the prince with a knife in his hand, he asked "where is the cow so I may kill it?" The patient then lowed like a cow to indicate where he was. "By order of the butcher, the patient was also laid on the ground for slaughter." When Avicenna approached the patient pretending to slaughter him, he said, "the cow is too lean and not ready to be killed. He must be fed properly, and I will kill it when it becomes healthy and fat." The patient was then offered food which he ate eagerly and gradually "gained strength, got rid of his delusion, and was completely cured" (Haque, 2004).

Ibn-Sina recognized 'physiological psychology' in treating illnesses involving emotions. From the clinical perspective Ibn-Sina developed a system for associating changes in the pulse rate with feelings, which has been viewed as a forerunner of the word-association test of Jung. He is said to have treated a very ill patient by feeling the patient's pulse and reciting aloud to him the names of provinces, districts, towns, streets and people. By noticing how the patient's pulse quickened when names were mentioned, Ibn-Sina deduced that the patient was in love with a girl whose home Ibn-Sina was able to locate by the digital 
examination. The man took Ibn-Sina's advice, married the girl, and recovered from his illness. It is not surprising, therefore, to know that an asylum for the mentally ill had been built by the early 8 th century at Fez, Morocco, and that insane asylums were also built by the Arabs in Baghdad in AD 705, in Cairo in AD 800, and in Damascus and Aleppo in AD 1270. In addition to baths, drugs, kind and benevolent treatment given to the mentally ill, music therapy and occupational therapy were also used. These therapies were highly developed. Special live music bands were brought in daily to entertain the patients by providing singing and music al performances, with comic performers as well.

\section{Neurosurgery}

Al-Zahrawi (Abulcasis) (Figure 7; Table 1) was considered the father of modern surgery as he developed material and technical designs that are still used in neurosurgery today. He was born in Al-Zahra, a suburb of Cordova. During his era, neurosurgery in the Islamic world became a respected specialty practiced by reputable physicians. On the other hand, European surgery was belittled and practiced by barbers and butchers. Therefore in AD 1163 the council of Tours declared the following resolution: "Surgery is to be abandoned by the schools of medic ine and by all decent physicians." Al-Zahrawi wrote about fracture of the skull (Al-Okbi 1971):

"The types of skull fractures are numerous, their shapes are different, and their causes are many. For example, some skull fractures are due to a blow by a sword that splits the whole skull and reaches the dura, the same as the ax does to the wood, therefore it is called axial fracture.

Sometimes the sword does not split the skull completely, it is thus called incomplete axial fracture. Such a fracture can be small or big. Another type is comminuted fracture, which can be due to a hit by a stone or a fall on a stone; and this fracture can reach the dura or only be limited to the outer part of the bone. This fracture can also be small or big. A third type is the hairy type of skull fracture which is so tiny and linear like a hair. A fourth type is the depressed fracture, which occurs due to a fall or a blow, so the bone is depressed like a brass jar when hit by a blunt instrument. This usually happens when the bone is soft as children. The types of these fractures are diagnosed by examining the wound, removing the debris and contused pan of the scalp, exposing the skull, and feeling it by the spatulas. The hairy fracture is difficult to discover and can be diagnosed by exposing the skull and smearing it with ink; the linear fracture thus appears stained." 


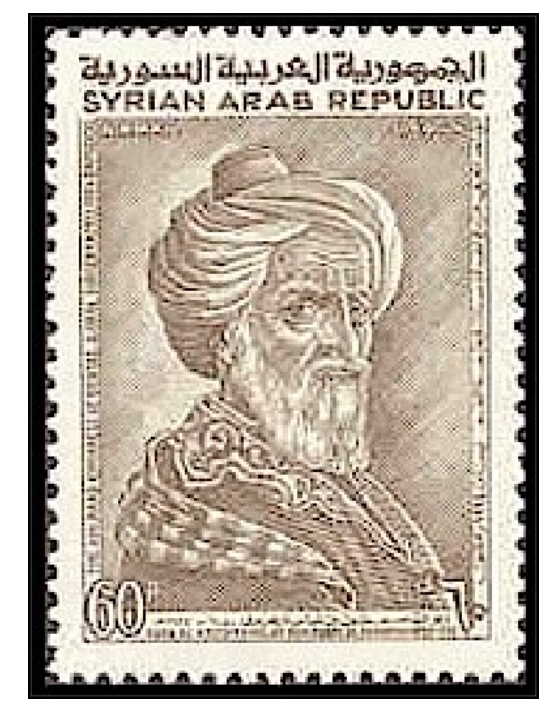

Figure 7: Al-Zahrawi - Albucasis.

Al-Zahrawi also wrote about the treatment of skull fractures using special instruments (Figure 8):

"If the patient shows serious signs such as high fever, repeated vomiting, exophthalmos, convulsions, and coma, do not touch him because he is probably going to die. Otherwise, treat him as follows: first shave the patient's head. In comminuted depressed fractures, these pieces of bone should be removed as will be explained. If in the process of the patient's examination or during surgery bleeding occurs, it can be controlled by pressure using towels soaked in alcohol and by wax. Then after control of the bleeding, the small pieces of bone are removed using special forceps. To remove the depressed fracture, first, make trephines in the healthy bone around it. These trephine instruments should not penetrate beyond the skull into the soft tissues' underneath; thus they are called non penetrating trephines. They have a rounded ring in their proximal end to prevent them from penetrating beyond certain depths. You should have a number of these trephines that can stop at different depths depending on the thickness of the skull. Connect the holes in the skull using special saws. First, use a fine small saw, then larger ones. These should be sharp and made of steel. Avoid cutting the dura by the trephine or saw. Once the depressed bone is freed, remove it gently, and then smoothen the edges of the skull by special instruments. Wash with alcohol and treat the wound with packs soaked with ointment." 


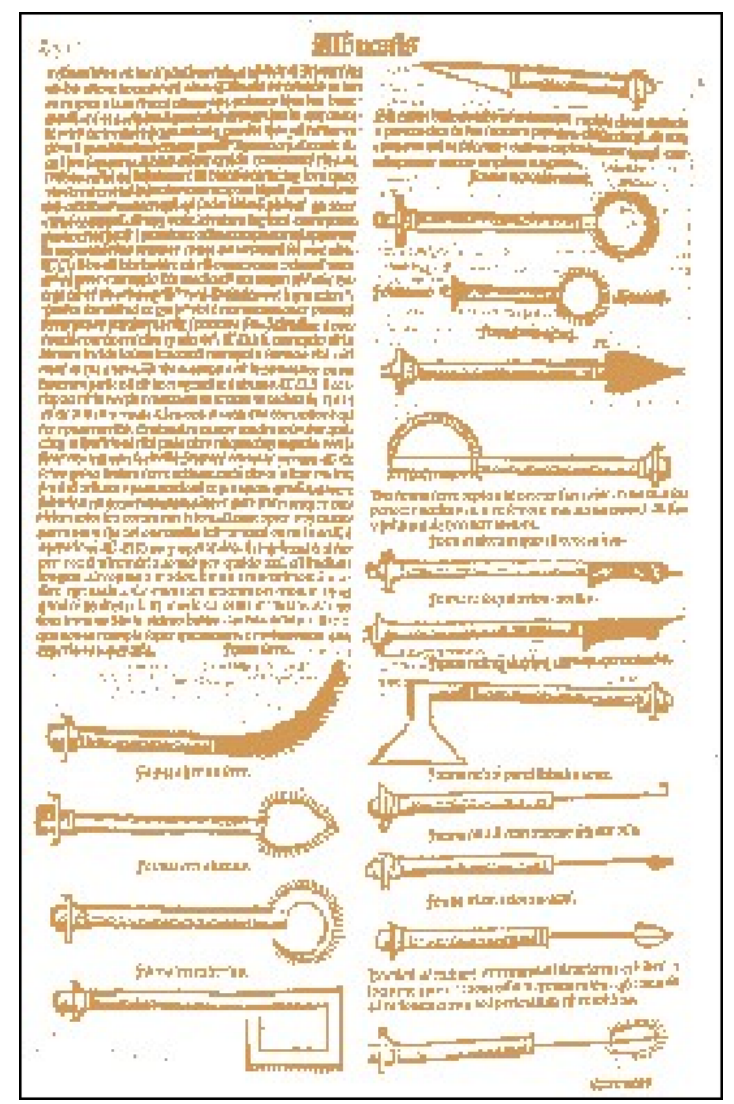

Figure 8: Page from a 1531 Latin translation by Peter Argellata of El Zahrawi's treatise on surgical and medic al instruments.

The Egyptian physician Ibn al-Nafis performed the earliest-known dissections on the human brain. Moreover, he corrected some of the incorrect theories of Galen and Avicenna on brain anatomy (Oataya, 1982).

\section{Arabs and anesthesia}

The Arabic physicians gave a detailed description of the pharmacology of important narcotics such as opium, hyoscyamus and hashish (Khairallal, 1942). Therefore Burton (1886) stated that "anesthetics have been used in surgery throughout the East for centuries before ether and chloroform became the fashion in the civilized West." In a Treatise on the Canon of Medicine by Avicenna (Ibn-Sina) under the article 814 Anesthetics (Skinner, 2001), several anesthetics are suggested:

"If it is desirable to get a person unconscious quickly, without him being harmed, add sweet smelling moss to the wine, or lignum aloes. If it is desirable to procure a deeply unconscious state, to enable the pain to be borne which is involved in painful applications to a member, place darnel-water into the wine, or administer fumitory, opium, hyoscyamus (half dram doses of each); nutmeg, crude aloes-wood (4 grains of each). Add this to the wine and take as much as is necessary for the purpose. Or boil black hyoscyamus in water, with mandragore bark, until it becomes red. Add this to the wine." 
The soporific sponge was first introduced by the Arabs. It was commonly used for anesthesia in the Middle Ages. It was soaked with aromatic s and narcotics to be sucked and then held under nostril leading to anesthesia prior to surgery (Keys and Wakim, 1971). More than 1,000 years ago Avicenna wrote about the effect of pain on ventilation (Gruner, 1930):

"Pain dissipates the bodily strength and interferes with the normal functions of the organs. The respiratory organs are inhibited from drawing in air, and consequently the act of breathing is interfered with, and the respiration becomes intermittent, rapid, or altogether unnatural in rhythm."

\section{Conclusion}

The Arabic-Islamic world added much to earlier achievements in medicine. They fostered the flame of civilization, made it brighter and handed it over to Europe, which in turn passed it to the USA, and the cycle continues. 1,000 years ago, Islamic medicine was the most advanced in the world. Even after ten centuries, the achievements of Islamic medicine appear amazingly modern. 1,000 years ago, Muslims were the great torchbearers of international scientific research. Every student and professional from each country outside the Islamic Empire aspired, yearned, and dreamed to go to the Islamic universities to learn, work and live in an affluent, advanced, and civilized society.

Unfortunately, Arab, and Muslim neuroscientists are now a long way back in their scientific production and achievement. That is partially because Islamophobia extends through the academic sphere. Islamophobia has rapidly spread to the public of science. Unfortunately, injustice appears to be a trait intrinsic to humans. Many people may at some stage have negative views based on their own social, cultural or religious background and viewpoint on an individual or an event or beliefs system. Usually, bias results from an inadequate awareness of certain people and groups' values, views, and history.

An example of this bias is Islamophobia. Every human being deserves dignity, respect and a safe and secure life in a pleasant world and country. Further, the advancement of civil rights and freedoms, as well as our multicultural heritage, can be measured by the advancement and preservation of the fundamental rights of every person. To eradicate and avoid bias in the scientific field, scientists and academics must have a better understanding of Islam and of Muslims. Such understanding can be achieved through three approaches: (1) The Concept of Contributions; (2) The Concept of Diversity; and (3) The Concept of Similarities (see Hossain, 2013 for more details).

This present article contributes modestly to strengthening Arab / Muslim scientists' current condition in relation to their optimistic past. In cooperation with individuals and institutes, the scientific community has immense responsibility for making science for all, irrespective of political issues. The article aims clearly to 
demonstrate some 'weeds' for the better science field in our science backyard.

\section{ON TO THE FUTURE}

The importance of neuroscience not only lies in its obvious relevance to human health and well-being, but also in the tremendous economic benefits it provides. We are encouraged to share the responsibility for increasing funding for biomedical research and improved science facilities for each Arab/Muslim state, not only by the scientific community but also by public and private funding organizations in Arab countries. Increased cooperation between Arab and Muslim countries and their neighbors would also bring significant benefits for the participants. Additionally, rich nations and regions such as the USA and Europe have an obligation to support the research output of Arab / Muslim countries. That can be achieved by getting well-trained Arab scientists into foreign research networks and encouraging them to remain in their own countries and thus improve the efficiency of local research and stop brain drains. In the Arab-Islamic Golden Ages in particular, Arabs have a long tradition of commitment to research. Political, social and economic problems in Arab countries however have hindered scientists, making it difficult for them to maximize their work productivity potential in most science fields including neuroscience.

Based on this article, even if we measure the Arab medicine developments to a minimum, I am trying to suggest that Arab medical history should be researched in a systematic and systemic way with deep concentrations (Brown, 2011). I conclude, therefore, with this famous saying, "The medicine was in primitive stage, Galen gave the life to it; was scattered, Razi compiled it; and it was haphazard, Ibn Sina systematized it”' (Tarabulsi, 1982).

\section{References}

Abbasi SS, Brasiliense LBC, Workman RK. The fate of medic al knowledge and the neurosciences during the time of Genghis Khan and the Mongolian Empire. Neurosurgical Focus. 2007; 23:E13, 3.

Ahmad W, Rabee K, Zulkifle M: Arab and Muslim contributions to Medicine and Research - A Review. Bangladesh Journal of Medical Science Vol. 16 No. 03 July'17.

Akbar SA. Al-Beruni: The first anthropologist. RAIN. 1984; 60:9-10.

Araguz MA, Martinez BC, Ajo FAV, Moreno-Martinez, JM. Neuroscience in al-Andalus and its influence on medieval scholastic medic ine. Revista de neurología. 2002; 34:877-92.

ARA Rashid. Increasing Muslim contribution to medical research; reviving a lost legacy. Bangladesh Journal of Medical Science. 2010; 09 (2): 64-67. DOI: http:// dx.doi.org/10.3329/bjms.v9i2.5653

Ashy MA. Health and illness from an Islamic perspective. Journal of Religion and Health. 1999; 38:241-57. 
Beg H. Surgical Principles of Ibn Sina (Avicenna). Bangladesh Journal of Medical Science. 2015;14(3): 217-220. DOI: http://dx.doi.org/10.3329/bjms. v14i3.22776

Brown EG. Arabian Medicine. Edn. I, Cambridge University Press, London; 2012; p 112-113, $115-116,114-11$

Deuraseh N, Abu Talib M. Mental health in Islamic medic al tradition. The International Medical Journal. 2005; 4:76-9.

Ezzat Abouleish. Contributions of Islam to Medicine. http://www.islam-usa.c om/im3.html

Falagas ME, Zarkadoulia EA, Samonis G. Arab science in the golden age (750-1258 C.E.) and today. FASEB J. 2006; 20:1581-6.

Gruner OC. A Treatise on the Canon of Medicine of Avicenna, Incorporating a Translation of the First Book, Luzac \& Co., London. 1930.

Haque A. Psychology from Islamic perspective: Contributions of early Muslim scholars and challenges to contemporary Muslim psychologists. Journal of Religion and Health. 2004; 43:357-77.

Hitti KP. Introduction. Descriptive Catalogue of the Garret Collection of Arabic Manuscript, Princeton University Press, London, 1938; p IV MTAIH

Hossain, K. (2013). Understanding Islam in the U.S. classroom. Multicultural Education. 20(2), 4952

Iqbal M. The Reconstruction of Religious Thought in Islam: The Spirit of Muslim Culture. Pakistan, Iqbal Academy. ISBN:969-416-286-6. 1999. http://www.allamaiqbal.c om/

Keys TE, Wakim KG. Contributions of the Arabs to medic ine. Mayo Clinic Proceedings of the Staff Meeting. 1971; 28:432-7.

Khairallah AA. Arabic contributions to anatomy and surgery. Ann. Med. Hist. 1942; 3:409-415.

Khaleefa $\mathrm{O}$. Who is the founder of psychophysics and experimental psychology? American Journal of Islamic Social Sciences. 1999; 16 (2).

Lutz PL. The Rise of Experimental Biology: An Illustrated History. Humana Press. 2002, p. 60. ISBN 0896038351.

Matthew E. Falagas, Effie A. Zarkadoulia and George Samonis. Arab science in the golden age (750-1258 C.E.) and today. The FASEB Journal, 2018; Vol. 20, No. 10, pp. 1581-1586.

Oataya S. Ibn al-Nafis has dissected the human body, Symposium on Ibn al-Nafis. Second International Conference on Islamic Medicine, Islamic Medical Organization, Kuwait, Encyclopedia of Islamic World. http://www.islamset.c om/isc /nafis/oataya.html. Retrieved 23 January 2008.

Paladin AV. Ethics and neurology in the Islamic world. Continuity and change. Ital. J Neurol Sci. 1998;19: 255-8.

Skinner P. Unani-Tibbi, Encyclopedia of Alternative Medicine. 2001. http://findarticles.com/p/articles/mi_g2603/is_0007/ai_2603000716.

Stanley F. Origins of Neuroscience: A History of Explorations into Brain Function. Oxford University Press, Oxford. 1994, p. 70. ISBN 0195146948.

Steffens B. Ibn al-Haytham: First Scientist, Chapter 5. Morgan Reynolds Publishing, Greensboro, NC. 2006. ISBN 1599350246. 
Sudan SA. Principles of Islamic counseling and psychotherapy. Asian Journal of Management Sciences \& Education Vol. 6(3) July 2017

Syed IB. Islamic medic ine: 1000 years ahead of its times. J. Islamic Med. Assoc. 2002; 2: 2-9.

Tarabulsi N. Sannajatut Tarab Fi Taqaddimatil Arab. Edn. II, Darur Raid Beruit, 1982; p 442-443, 437

Theodore M. Masters of the Mind: Exploring the Story of Mental Illness from Ancient Times to the New Millennium, John Wiley \& Sons. 2004, p. 38. ISBN0471679615.

Youssef HA, Youssef FA. Evidence for the existence of schizophrenia in medieval Islamic society. History of Psychiatry. 1996; 7: 55-62.

Zahoor A and Haq Z. George Sarton: Introduction to the History of Science. Quotations from Famous Historians of Science, Cyberistan. 1997. http://www.cyberistan.org/islamic/Introl1.html 